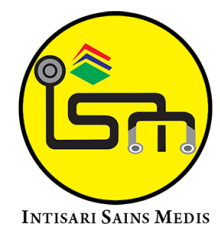

Published by Intisari Sains Medis

\section{Disseminated Intravascular Coagulation (DIC) akibat gigitan ular: laporan kasus}

Ni Komang Krisnawati ${ }^{*}$, Ida Ayu Putri Wirawati ${ }^{2}$, Sianny Herawati ${ }^{2}$, Ni Nyoman Mahartini ${ }^{2}$, Anak Agung Ayu Lydia Prawita' ${ }^{1}$ Ekarini Katharina Yunarti Nabu' ${ }^{1}$

\begin{abstract}
Background: Snakebite cases are cases of emergency that are often found in the Emergency Unit, especially in rice fields, forests, plantations and swamps. There is no definitive data on the number of snakebite cases in Indonesia. Morbidity and mortality of snakebite cases are highly dependent on the type of snake species, the number and type of can that enter the body, as well as the availability of anti-snake serum. In these patients were found Disseminated Intravascular Coagulation (DIC) due to snake bites.

Case Presentation: A 5-years female patient complained of pain in the right hand due to snakebite about 30 minutes before entering the hospital. The snake is green with a red tail, a triangular head shape and a length of about 30 centimeters, biting the middle finger of the patient's right hand. Swollen
\end{abstract}

redness and pain are felt spreading to the shoulders. Physical examination of compos mentis patients with a pulse rate of 96 times per minute, breath rate of 20 times per minute and temperature of $36.7^{\circ} \mathrm{C}$. There was found edema and bullae in digiti III in the right manus region, palpably warm, and there is press pain. In the antebrachial region to the right humerus also found the presence of edema and press pain. Patients with normochromic normositer anemia with thrombocytopenia as well as lengthening of coagulation physiology decreased fibrinogen and increased D-dimer.

Conclusion: Snake venom can be hemotoxic, neurotoxic and cytotoxic. Snakebite cases require rapid and comprehensive management to minimize the possibility of disability and death.

Keywords: Disseminated Intravascular Coagulation, Snakebite, Case Report.

Cite This Article: Krisnawati, N.K., Wirawati, I.A.P., Herawati, S., Mahartini, N.N., Prawita, A.A.A.L., Nabu, E.K.Y. 2021. Disseminated Intravascular Coagulation (DIC) akibat gigitan ular: laporan kasus. Intisari Sains Medis 12(2): 586-590. DOI: $10.15562 /$ ism.v12i2.1050

\section{ABSTRAK}

Latar Belakang: Kasus gigitan ular merupakan kasus kegawatan yang sering dijumpai di Unit Gawat Darurat terutama di daerah area persawahan, hutan, perkebunan dan rawa. Tidak ada data yang pasti mengenai jumlah kasus gigitan ular di Indonesia. Morbiditas dan mortalitas kasus gigitan ular sangat tergantung dari jenis spesies ular, jumlah dan jenis bisa yang masuk ke dalam tubuh serta ketersediaan serum anti bisa ular.

PProgram Pendidikan Dokter Spesialis IImu Patolog Klinik, Fakultas Kedokteran, Universitas Udayana, RSUP Sanglah, Bali, Indonesia;

2Departemen Patologi Klinik, Fakultas Kedokteran, Universitas Udayana, RSUP Sanglah, Bali, Indonesia;

\footnotetext{
*Korespondensi:

Ni Komang Krisnawati;

Program Pendidikan Dokter Spesialis IImu Patologi Klinik, Fakultas Kedokteran, Universitas Udayana, RSUP Sanglah, Bali, Indonesia;

komangkrisnawati99@gmail.com
}

Presentasi Kasus: Pada pasien ini ditemukan Disseminated Intravascular Coagulation (DIC) akibat gigitan ular. Pasien perempuan, usia 5 tahun dengan keluhan nyeri pada tangan kanan akibat gigitan ular sejak sekitar 30 menit sebelum masuk rumah sakit. Ular berwarna hijau dengan ekor merah, bentuk kepala segitiga dan panjang sekitar 30 centimeter, menggigit jari tengah tangan kanan pasien. Bengkak

kemerahan dan nyeri dirasakan menjalar sampai ke bahu. Pemeriksaan fisik pasien compos mentis dengan laju nadi 96 kali per menit, laju nafas 20 kali per menit dan suhu $36,7^{\circ} \mathrm{C}$. Pada regio manus kanan ditemukan adanya edema dan bullae pada digiti III, teraba hangat dan terdapat nyeri tekan. Pada region antebrachii sampai humerus kanan juga ditemukan adanya edema dan nyeri tekan. Pasien mengalami anemia normokromik normositer dengan trombositopenia serta pemanjangan faal koagulasi, penurunan fibrinogen dan peningkatan D-dimer.

Kesimpulan: Bisa ular dapat bersifat hemotoksik, neurotoksik dan sitotoksik. Kasus gigitan ular memerlukan penatalaksanaan yang cepat dan komprehensif sehingga dapat meminimalkan kemungkinan kecacatan dan kematian.

Kata kunci: Disseminated Intravascular Coagulation, Gigitan Ular, Laporan Kasus.

Sitasi Artikel ini: Krisnawati, N.K., Wirawati, I.A.P., Herawati, S., Mahartini, N.N., Prawita, A.A.A.L., Nabu, E.K.Y. 2021. Disseminated Intravascular Coagulation (DIC) akibat gigitan ular: laporan kasus. Intisari Sains Medis 12(2): 586-590. D0I: 10.15562/ism.v12i2.1050 


\section{PENDAHULUAN}

Kasus gigitan ular merupakan kasus kegawatan yang sering dijumpai di Unit Gawat Darurat terutama di daerah area persawahan, hutan, perkebunan dan rawa. ${ }^{1}$ Tidak ada data yang pasti mengenai jumlah kasus gigitan ular di Indonesia. Menurut data WHO, diperkirakan terdapat 421 ribu kasus gigitan ular, dimana setiap tahunnya terdapat 20 ribu kematian karena kasus gigitan ular di Asia Selatan, Asia Tenggara dan Sub Sahara Afrika. ${ }^{2}$ Morbiditas dan mortalitas kasus gigitan ular sangat tergantung dari jenis spesies ular, jumlah dan jenis bisa yang masuk ke dalam tubuh serta ketersediaan serum anti bisa ular. Gigitan ular beracun dapat menyebabkan kecacatan maupun kematian bila tidak mendapat pertolongan dengan baik. ${ }^{3}$

Gejala dan tanda-tanda gigitan ular akan bervariasi sesuai spesies ular yang menggigit dan banyaknya bisa yang diinjeksikan pada korban. ${ }^{4}$ Gejala dan tanda-tanda tersebut antara lain adalah tanda adanya bekas gigitan taring (fang marks), nyeri lokal, perdarahan lokal, memar, pembengkakan kelenjar getah bening, radang, melepuh, infeksi lokal dan nekrosis jaringan. ${ }^{4}$ Secara laboratorium dapat ditemukan kelainan seperti anemia karena hemolisis intravaskular, trombositopenia, hematuria, hipofibrinogenemia, peningkatan kadar D-dimer. ${ }^{5}$
Salah satu komplikasi yang dapat mengancam jiwa pada gigitan ular berbisa adalah kejadian Disseminated Intravascular Coagulation (DIC). Scientific and Standardization Committee (SSC) pada DIC terhadap International Society on Thrombosis and Haemostasis (ISTH) mendefinisikan DIC sebagai sindrom didapat yang ditandai dengan aktivasi koagulasi intravaskular dari penyebab yang berbeda. Hal ini dapat menyebabkan kerusakan mikrovaskuler, yang jika parah dapat menyebabkan disfungsi organ. ${ }^{6}$ Definisi tersebut memberi perhatian bahwa DIC merujuk pada indikasi pembentukan trombin sistemik yang tidak terbatas pada tempat kerusakan dan cedera sel endotel, yang menimbulkan disfungsi organ. ${ }^{6,7}$ Bersama dengan perubahan-perubahan ini, penghambatan fibrinolisis secara sinergis menghasilkan trombosis mikrovaskular, bersama dengan gangguan hemodinamik dan metabolik, turut berkontribusi pada disfungsi organ. Oleh karena itu DIC merupakan prediktor independen kematian pada penyakit kritis dan sering terjadi pada gigitan ular berbisa. $^{7}$

Berdasarkan pada pemaparan di atas, laporan kasus ini akan mengevaluasi kejadian DIC akibat gigitan ular terutama dalam evaluasi laboratorium dan luaran klinis pasien yang terdapat di RSUP Sanglah, Bali, Indonesia.

\section{LAPORAN KASUS}

Pasien perempuan usia 5 tahun mengeluh nyeri pada tangan kanan. Nyeri pada tangan kanan akibat gigitan ular sejak sekitar 30 menit sebelum masuk rumah sakit. Ular berwarna hijau dengan ekor merah, bentuk kepala segitiga dan panjang sekitar 30 centimeter, menggigit jari tengah tangan kanan pasien. Bengkak kemerahan dan nyeri dirasakan menjalar sampai ke bahu. Pasien menangis kuat, tidak ada demam. Riwayat pingsan, kejang dan muntah tidak ada. Tidak ada mimisan, tidak ada gusi berdarah, tidak ada perdarahan di bawah kulit, tidak ada buang air besar berwarna hitam. Buang air kecil jernih, nyeri kepala dan nyeri perut disangkal. Penderita tidak pernah mengalami keluhan yang sama sebelumnya. Riwayat alergi tidak ada. Tidak ada keluarga pasien mengalami keluhan yang sama dengan pasien.

Pemeriksaan fisik didapatkan pasien compos mentis, laju nadi 96 kali per menit, laju napas 20 kali per menit dan suhu $36,7^{\circ} \mathrm{C}$. Tidak ditemukan adanya anemis dan ikterus. Pembesaran kelenjar getah bening juga tidak ada. Akral teraba hangat dengan capillary refill time $<2$ detik. Pada regio manus kanan ditemukan adanya edema dan bullae pada digiti III, teraba hangat dan terdapat nyeri tekan. Pada region antebrachii sampai humerus kanan juga ditemukan adanya edema dan nyeri tekan.

Tabel 1. Hasil pemeriksaan darah lengkap

\begin{tabular}{|c|c|c|c|c|c|c|c|}
\hline Parameter & $15 / 11 / 19$ & $17 / 11 / 19$ & 20/11/19 & $21 / 11 / 19$ & 22/11/19 & 23/11/19 & Nilai Rujukan \\
\hline $\mathrm{WBC}\left(10^{3} / \mu \mathrm{L}\right)$ & 14,21 & 15,33 & 9,91 & 13,07 & 15,03 & 11,70 & $4,10-11,00$ \\
\hline \%Neu & 54,59 & 84,41 & 65,43 & 73,94 & 47,19 & 81,40 & $47,00-80,00$ \\
\hline \%Lym & 37,05 & 11,24 & 27,51 & 17,66 & 41,92 & 15,50 & $13,00-40,00$ \\
\hline \%Mono & 6,71 & 4,05 & 5,75 & 7,87 & 9,11 & 2,85 & $2,00-11,00$ \\
\hline$\%$ Eos & 0,98 & 0,01 & 0,05 & 0,00 & 0,76 & 0,02 & $0,00-5,00$ \\
\hline \%Baso & 0,66 & 0,29 & 1,26 & 0,53 & 1,02 & 0,23 & $0,00-2,00$ \\
\hline $\operatorname{RBC}\left(10^{6} / \mu \mathrm{L}\right)$ & 5,34 & 5,04 & 4,07 & 4,33 & 4,04 & 4,07 & $4,50-5,90$ \\
\hline $\mathrm{HGB}(\mathrm{g} / \mathrm{dL})$ & 13,51 & 12,66 & 10,47 & 11,01 & 10,85 & 11,05 & $13,50-17,50$ \\
\hline $\operatorname{HCT}(\%)$ & 40,60 & 38,64 & 31,06 & 33,16 & 31,70 & 31,82 & $41,00-53,00$ \\
\hline MCV (fL) & 76,06 & 76,69 & 76,40 & 76,52 & 78,54 & 78,27 & $80,00-100,00$ \\
\hline $\mathrm{MCH}(\mathrm{pg})$ & 25,31 & 25,13 & 25,76 & 25,40 & 26,87 & 27,18 & $26,00-34,00$ \\
\hline $\operatorname{MCHC}(\mathrm{g} / \mathrm{dL})$ & 33,28 & 32,77 & 33,72 & 33,19 & 34,22 & 34,72 & $31,00-36,00$ \\
\hline RDW (\%) & 12,22 & 12,95 & 12,56 & 12,19 & 12,56 & 12,89 & $11,60-14,80$ \\
\hline $\operatorname{PLT}(10 \mu / \mu \mathrm{L})$ & 306,70 & 143,20 & 44,33 & 98,85 & 170,50 & 207,80 & $150,00-440,00$ \\
\hline MPV (fL) & 6,62 & 7,56 & 9,05 & 9,20 & 6,25 & 6,25 & $6,80-10,00$ \\
\hline
\end{tabular}

WBC: White Blood Cells; RBC: Red Blood Cells; HGB: Haemoglobin; HCT: Haematocrit; MCV: Mean Corpuscular Volume; MCH: Mean Corpuscular Haemoglobin; MCHC: Mean Corpuscular Haemoglobin Concentration; RDW: Red-Cell Distribution Width; PLT: Platelet; MPV: Mean Platelet Volume; Neu: Neutrophils; Lym: Lymphocytes; Mono: Monocytes; Eos: Eosinophils; Baso: Basophils. 
Tabel 2. Pemeriksaan faal hemostasis, kimia klinik, dan urinalisis

\begin{tabular}{|c|c|c|c|c|c|c|c|}
\hline Parameter & $15 / 11 / 19$ & $17 / 11 / 19$ & 20/11/19 & $21 / 11 / 19$ & $22 / 11 / 19$ & $23 / 11 / 19$ & Nilai Rujukan \\
\hline PPT (detik) & 15,10 & 25,00 & 48,80 & - & 21,50 & 14,00 & $10,80-14,40$ \\
\hline INR & 1,08 & 1,57 & 3,62 & - & 1,56 & 1,00 & $0,90-1,10$ \\
\hline APTT (detik) & 31,1 & 39,10 & 60,90 & - & 30,70 & 26,10 & $24,00-36,00$ \\
\hline Fibrinogen $(\mathrm{mg} / \mathrm{dl})$ & - & - & - & $<25,00$ & - & - & $140,00-450,00$ \\
\hline D-dimer $(\mu \mathrm{g} F E U / m l)$ & - & - & - & 9,58 & - & - & $<0,50$ \\
\hline SGOT (U/L) & 32,0 & - & - & 24,50 & - & - & $11,00-33.00$ \\
\hline SGPT (U/L) & 26,30 & - & - & 36.70 & - & - & $11,00-50.00$ \\
\hline Bilirubin Total (mg/dL) & - & - & - & 0,38 & - & - & $0,00-1.00$ \\
\hline Bilirubin Direk (mg/dL) & - & - & - & 0,15 & - & - & $0,00-0.30$ \\
\hline Bilirubin Indirek (mg/dL) & - & - & - & 0,23 & - & - & - \\
\hline $\mathrm{BUN}(\mathrm{mg} / \mathrm{dL})$ & 15,50 & - & - & 10,50 & - & - & $8,00-23,00$ \\
\hline Kreatinin $(\mathrm{mg} / \mathrm{dL})$ & 0,56 & - & - & 0,43 & - & - & $0,50-0,90$ \\
\hline Kalsium (Ca) (mg/dL) & - & - & - & 9,50 & - & - & $9,20-11,00$ \\
\hline Natrium $(\mathrm{mmol} / \mathrm{L})$ & 138,00 & - & - & 138,00 & - & - & $136,00-145,00$ \\
\hline Kalium (mmol/L) & 3,60 & - & - & 3,85 & - & - & $3,50-5,10$ \\
\hline Klorida $(\mathrm{Cl})(\mathrm{mmol} / \mathrm{L})$ & 102,90 & - & - & 102,10 & - & - & $94,00-110,00$ \\
\hline Berat Jenis & - & - & - & 1,010 & - & - & $1,003-1,035$ \\
\hline $\mathrm{pH}$ & - & - & - & 7,00 & - & - & $4,50-8,00$ \\
\hline Leukosit (leuko/uL) & - & - & - & Negatif & - & - & Negatif \\
\hline Nitrit $(\mathrm{mg} / \mathrm{dL})$ & - & - & - & Negatif & - & - & Negatif \\
\hline Protein $(\mathrm{mg} / \mathrm{dL})$ & - & - & - & Negatif & - & - & Negatif \\
\hline Glukosa (mg/dL) & - & - & - & Negatif & - & - & Negatif \\
\hline Keton $(\mathrm{mg} / \mathrm{dL})$ & - & - & - & Negatif & - & - & Negatif \\
\hline Darah (ery/uL) & - & - & - & Negatif & - & - & Negatif \\
\hline Urobilinogen $(\mathrm{mg} / \mathrm{dL})$ & - & - & - & Normal & - & - & Normal \\
\hline Bilirubin (mg/dL) & - & - & - & Negatif & - & - & Negatif \\
\hline Warna & - & - & - & Yellow & - & - & Pale Yellow-Yellow \\
\hline Leukosit Sedimen (/LBP) & - & - & - & 2 & - & - & $\leq 7$ \\
\hline Eritrosit Sedimen (/LBP) & - & - & - & 5 & - & - & $\leq 5$ \\
\hline \multicolumn{8}{|l|}{ Sel Epitel Sedimen } \\
\hline Gepeng (/LBP) & - & - & - & 0 & - & - & - \\
\hline Kristal & - & - & - & Negatif & - & - & - \\
\hline Lain-lain (/LBP) & - & - & - & Negatif & - & - & - \\
\hline Hemoglobin Urin & - & - & - & Negatif & - & - & - \\
\hline
\end{tabular}

PTT: Partial Thromboplastin Time; APTT: Activated Partial Thromboplastin Time; INR: International Normalized Ratio; SGOT: Serum Glutamic Oxaloacetic Transaminase; SGPT: Serum Glutamic Pyruvic Transaminase; BUN: Blood Urea Nitrogen

Hasil pemeriksaan darah lengkap pada saat awal pasien dirawat menunjukkan adanya leukositosis ringan oleh karena peningkatan ringan sel neutrofil (Tabel 1). Pasien juga mengalami penurunan hemoglobin dan penurunan trombosit dari saat awal pasien dirawat hingga hari ke-5 perawatan, kemudian perlahan kembali normal (Tabel 1).

Hasil pemeriksaan faal hemostasis pada pasien menunjukkan adanya pemanjangan faal koagulasi, penurunan fibrinogen serta peningkatan D-dimer (Tabel 2). Sedangkan pada hasil evaluasi apusan darah tepi didapatkan anemia normokromik normositer dengan ditemukan adanya fragmentosit serta trombositopenia (Gambar 1). Hasil pemeriksaan kimia klinik pasien dalam batas normal sedangkan hasil pemeriksaan urinalisis juga ditemukan dalam batas normal dan tidak ditemukan adanya hemoglobinuria pada pasien (Tabel 2).

Berdasarkan pada hasil pemeriksaan laboratorium tersebut, pasien terdiagnosis dengan Disseminated Intravascular Coagulation (DIC), disertai dengan keadaan anemia ringan normokromik normositer et causa suspek proses hemolitik et causa snake bite region manus kanan. Pasien mendapatkan terapi $\mathrm{ABU}$, deksametason, difenhidramin serta parasetamol. Evaluasi laboratorium dilakukan secara berkala dari tanggal 15 November 2019 hingga 23 November 2019 di RSUP Sanglah, Bali, Indonesia.

\section{PEMBAHASAN}

Ular merupakan jenis hewan melata yang banyak terdapat di Indonesia. Spesies ular dapat dibedakan atas ular berbisa dan ular tidak berbisa. Ciri-ciri ular tidak berbisa adalah bentuk kepala segiempat panjang, gigi taring kecil dan bekas gigitan memberikan gambaran luka halus berbentuk lengkungan. ${ }^{1}$ Ciri-ciri ular berbisa adalah bentuk kepala segitiga, dua gigi taring besar di rahang atas dan bekas gigitan memberikan gambaran dua luka gigitan utama akibat gigi taring. Pada taring ular berbisa terdapat saluran untuk menginjeksikan bisa ke dalam tubuh mangsanya secara subkutan atau intramuskular. Bisa adalah suatu zat atau substansi yang berfungsi untuk 


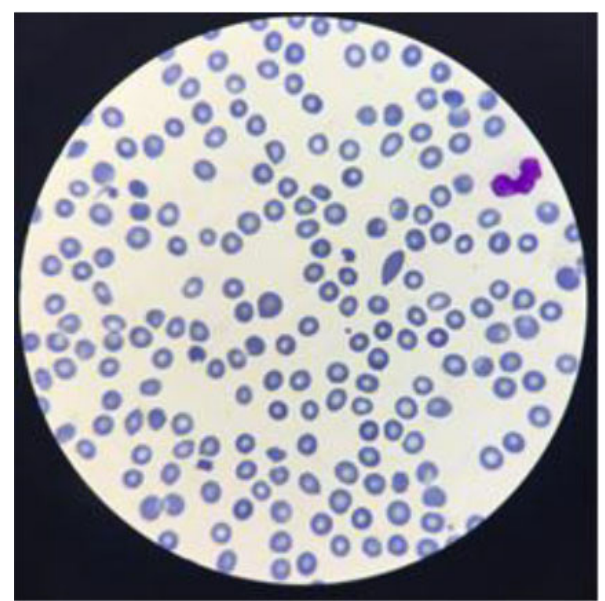

Gambar 1. Anemia

normositer

normokromik

ditemukan

fragmentosit

dengan

adanya

trombositopenia.

melumpuhkan mangsa dan sekaligus juga berperan untuk pertahanan diri. ${ }^{1}$ Efek toksik bisa ular pada saat menggigit mangsanya tergantung dari spesies, ukuran ular, usia dan efisiensi mekanik gigitan (apakah hanya satu atau kedua taring menusuk kulit) serta banyaknya serangan yang terjadi. ${ }^{1}$

Berdasarkan sifatnya pada tubuh mangsa, bisa ular dapat dibedakan menjadi bisa hemotoksik, yaitu bisa yang dapat mempengaruhi jantung dan sistem pembuluh darah, bisa neurotoksik yaitu bisa yang dapat mempengaruhi sistem saraf dan otak dan bisa sitotoksik yaitu bisa yang hanya bekerja pada lokasi gigitan. Bisa ular terdiri dari $90 \%$ protein. Protein pada bisa ular terdiri dari enzim, toksin non enzimatik polipeptida dan protein non toksin (nerve growth factor). ${ }^{8}$

Pada anamnesa diketahui bahwa ular yang menggigit pasien berwarna hijau dengan bentuk kepala segitiga. Kemungkinan merupakan ular yang berbisa. Pada pemeriksaan fisik didapatkan laju nafas pasien dalam batas normal (20 kali per menit). Hal ini menandakan tidak terjadi komplikasi paralisis otototot pernafasan akibat pengaruh bisa neurotoksik. Pada pemeriksaan fisik pada tangan kanan dan lengan kanan didapatkan sekitar luka tampak bengkak kemerahan dan nyeri dirasakan menjalar sampai ke bahu. Keluhan ini merupakan efek sitotoksik dan neurotoksik bisa ular pada daerah gigitan. ${ }^{1}$

Pada pemeriksaan laboratorium didapatkan penurunan kadar hemoglobin. Pada hapusan darah tepi didapatkan kelainan morfologi eritrosit yaitu adanya fragmentosit akibat proses hemolisis intravaskuler. Leukositosis ringan oleh karena peningkatan ringan sel neutrofil disebabkan oleh karena adanya proses inflamasi. Trombositopenia terjadi karena penggunaan trombosit pada proses DIC akut akibat aktivasi oleh bisa ular. Trombosit penting dalam pembentukan sumbat hemostasis dan menjaga hemostasis normal. ${ }^{9}$

Disseminated intravascular coagulation (DIC) didefinisikan sebagai kelainan sistemik trombohemoragik, merupakan suatu kondisi klinis sekunder terhadap penyakit dasarnya, dan dihubungkan dengan terdapatnya bukti berupa gejala klinik dan parameter laboratorium yaitu aktivasi koagulasi, aktivasi fibrinolisis, konsumsi inhibitor, dan penanda biokimia yang membuktikan adanya kerusakan atau kegagalan organ tahap akhir. ${ }^{10}$

Secara umum DIC dapat dibagi menjadi dua yaitu compensated DIC atau non-overt DIC dan decompensated DIC atau overtDIC. ${ }^{11}$ Proses disseminated intravascular coagulation biasanya diawali dengan keadaaan compensated DIC kemudian berlanjut dengan decompensated DIC. Pada keadaan compensated DIC terdapat dua tahap yaitu pertama hiperkoagulabilitas serta kedua fibrinolisis sekunder. Pada keadaan compensated DIC ditandai dengan terjadinya aktivasi koagulasi sehingga terjadi pemakaian trombosit dan faktor-faktor koagulasi lebih dari normal akan tetapi hal tersebut masih dapat terkompensasi sehingga bila dilakukan pemeriksaan parameter hemostasis masih dapat memberikan hasil normal. ${ }^{11}$

Diagnosis DIC didasarkan pada berbagai gambaran klinis serta laboratorium. The International Society on Thrombosis and Haemostasis (ISTH) mengembangkan sebuah skoring sederhana untuk mendiagnosis DIC overt dan DIC non overt dengan menggunakan parameter laboratorium yang tersedia dihampir seluruh rumah sakit. ${ }^{12}$ Skor 5 atau lebih mengindikasikan suatu DIC yang nyata (DIC overt), namun skor kurang dari 5 tidak mengeksklusikan DIC namun dapat berupa suatu DIC yang tidak nyata (DIC non overt). ${ }^{13}$ Sensitivitas sistem skoring ini adalah 91-93\% dan spesifisitasnya $97-98 \% .{ }^{14}$ Pada pasien ini didapatkan skor 7 .

Pada kasus ini bisa ular mengaktivasi sistem koagulasi dan terjadinya fibrinolisis. Dapat dilihat dari kadar fibrinogen menurun dan kadar D-dimer meningkat. Pada pemeriksaan laboratorium penderita didapatkan hasil pemeriksaan protrombin time (PT), international normalized ratio (INR) dan Activated Partial Thromboplastin Time (APTT) memanjang. Pemeriksaan PT digunakan untuk menilai aktivasi faktor koagulasi melalui jalur ekstrinsik dan jalur bersama yaitu faktor pembekuan VII, $\mathrm{X}, \mathrm{V}$, protrombin, fibrinogen dan faktor jaringan. Pemeriksaan APTT digunakan untuk menilai aktivitas faktor koagulasi melalui jalur intrinsik dan jalur bersama yaitu faktor pembekuan XII, XI, VIII, X, $\mathrm{V}$, protrombin dan fibrinogen. ${ }^{15}$

Pada pemeriksaan laboratorium didapatkan kadar fibrinogen penderita menurun. Fibrinogen adalah glikoprotein dengan berat molekul 340.000 dalton. Fibrinogen disintesis di hati (1,7-5 g/ hari). Penurunan kadar fibrinogen pada penderita dapat disebabkan karena perubahan fibrinogen menjadi fibrin oleh bisa ular. ${ }^{16}$

Bisa ular dapat mengaktivasi faktor $\mathrm{X}$ menjadi Xa (aktif) atau mengubah protrombin menjadi trombin. Trombin akan mengubah fibrinogen menjadi fibrin. Keadaan ini akan menyebabkan terbentuknya trombus yang berlebihan serta meluas pada pembuluh darah. Trombus dapat menyebabkan gangguan mekanik pada membran eritrosit menyebabkan hemolisis intravaskuler. ${ }^{8}$

D-dimer adalah produk akhir degradasi fibrin oleh plasmin yang terdiri atas dua fragmen $D$ pada proses fibrinolisis sekunder. ${ }^{17}$ Plasmin memecahkan fibrin ikat silang sehingga dihasilkan fragmen $\mathrm{X}$ dan $\mathrm{D}$ dengan ukuran yang berbeda. Pada keadaan normal kadar D-dimer dalam darah antara $8-135 \mathrm{ng} / \mathrm{mL}^{17}$ Plasmin bekerja memecahkan fibrin dan fibrinogen. Pada fibrinolisis primer plasmin memecahkan fibrinogen dan menghasilkan fragmen X, 
Y, D dan E yang merupakan fibrinogen degradation products. Pada DIC pembentukan D-dimer sebagai penanda adanya pembentukan trombin disertai pembentukan plasmin. ${ }^{17}$

Pemeriksaan kadar enzim AST (aspartate aminotransferase) dan kadar enzim ALT (alanine aminotransferase) dalam batas normal. Pemeriksaan ini dilakukan untuk menilai fungsi hepar penderita. Bila terjadi kerusakan hepatosit oleh karena pengaruh bisa ular, akan terjadi peningkatan enzim ALT dan AST. Fungsi hati penderita tidak mengalami gangguan yang disebabkan oleh bisa ular, sehingga sintesis fibrinogen tidak terganggu. Pemeriksaan ureum dan kreatinin pada pasien dalam batas normal, yang menandakan bahwa fungsi ginjal pasien normal.

Serum anti bisa ular (SABU) merupakan serum polivalen yang berasal dari plasma kuda yang diberikan kekebalan terhadap bisa ular yang mempunyai efek neurotoksik dan hemotoksik yang ada di Indonesia. Indikasi SABU adalah untuk pengobatan terhadap gigitan ular berbisa. ${ }^{1}$ Pada pasien direncanakan transfusi PRC, TC, FFP dan Cryoprecipitate bila terjadi perdarahan. Namun selama observasi di ruang intensif pasien tidak menunjukkan tanda-tanda perdarahan dan hasil pemeriksaan faal koagulasi pasien menunjukkan perbaikan sehingga transfusi tidak dilakukan. Pasien secara klinis dan laboratorium menunjukkan perbaikan dan dipulangkan.

\section{SIMPULAN}

Spesies ular dapat dibedakan atas ular berbisa dan ular tidak berbisa. Bisa ular dapat bersifat hemotoksik, neurotoksik dan sitotoksik. Kasus gigitan ular memerlukan penatalaksanaan yang cepat dan komprehensif sehingga dapat meminimalkan kemungkinan kecacatan dan kematian.

\section{KONFLIK KEPENTINGAN}

Tidak terdapat konflik kepentingan dalam penulisan laporan kasus ini.

\section{ETIKA PENULISAN}

Laporan kasus ini telah disusun berdasarkan etika publikasi menggunakan pedoman COPE dan ICMJE serta telah mendapatkan persetujuan tertulis (informed consent) dari pasien.

\section{PENDANAAN}

Tidak ada.

\section{KONTRIBUSI PENULIS}

Seluruh penulis memiliki kontribusi yang sama dalam penulisan laporan kasus ini baik dari pemilihan kasus, pengumpulan data, analisis data, hingga penulisan laporan kasus dalam bentuk publikasi ilmiah.

\section{DAFTAR PUSTAKA}

1. Warrell DA. Snake bite. Lancet. 2010;375(9708):77-88.

2. Chippaux JP. Epidemiology of snakebites in Europe: a systematic review of the literature. Toxicon. 2012;59(1):86-99.

3. Waiddyanatha S, Silva A, Siribaddana S, Isbister GK. Long-term Effects of Snake Envenoming. Toxins (Basel). 2019;11(4):193.

4. Kumar KS, Narayanan S, Udayabhaskaran V, Thulaseedharan NK. Clinical and epidemiologic profile and predictors of outcome of poisonous snake bites - an analysis of 1,500 cases from a tertiary care center in Malabar, North Kerala, India. Int J Gen Med. 2018;11:209-216.

5. Braud S, Bon C, Wisner A. Snake venom proteins acting on hemostasis. Biochimie. 2000;82(9-10):851-859. doi:10.1016/s03009084(00)01178-0

6. Gando S, Levi M, Toh CH. Disseminated intravascular coagulation. Nat Rev Dis Primers. 2016;2:16037.

7. Sartim MA, Cezarette GN, Jacob-Ferreira AL, Frantz FG, Faccioli LH, Sampaio SV. Disseminated intravascular coagulation caused by moojenactivase, a procoagulant snake venom metalloprotease. Int J Biol Macromol. 2017;103:1077-1086.

8. Hodgson WC, Wickramaratna JC. Snake venoms and their toxins: an Australian perspective. Toxicon. 2006;48(7):931-940.

9. Lu Q, Clemetson JM, Clemetson KJ. Snake venoms and hemostasis. J Thromb Haemost. 2005;3(8):1791-1799.

10. Boral BM, Williams DJ, Boral LI. Disseminated Intravascular Coagulation. Am J Clin Pathol. 2016;146(6):670-680.

11. Wada H, Thachil J, Di Nisio M, Mathew P, Kurosawa S, Gando S, et al. Guidance for diagnosis and treatment of DIC from harmonization of the recommendations from three guidelines. J Thromb Haemost. 2013;11(4):761-767.

12. Papageorgiou C, Jourdi G, Adjambri E, Walborn A, Patel P, Fareed J, et al. Disseminated Intravascular Coagulation: An Update on Pathogenesis, Diagnosis, and Therapeutic Strategies. Clin Appl Thromb Hemost. 2018;24(9_suppl):8S-28S.

13. Toh $\mathrm{CH}$, Hoots WK; SSC on Disseminated Intravascular Coagulation of the ISTH. The scoring system of the Scientific and Standardisation Committee on Disseminated Intravascular Coagulation of the International Society on Thrombosis and Haemostasis: a 5-year overview. J Thromb Haemost. 2007;5(3):604-6.

14. Moffat KA, Kiencke V, Blanco AN, McLintock C, Peyvandi F, de Maat MPM, et al. International Society on Thrombosis and Haemostasis core curriculum project: Core competencies in laboratory thrombosis and hemostasis. J Thromb Haemost. 2019;17(11):1848-1859.

15. Winter WE, Flax SD, Harris NS. Coagulation Testing in the Core Laboratory. Lab Med. 2017;48(4):295-313.

16. Winter WE, Greene DN, Beal SG, et al. Clotting factors: Clinical biochemistry and their roles as plasma enzymes. Adv Clin Chem. 2020;94:3184.

17. Linkins LA, Takach Lapner S. Review of D-dimer testing: Good, Bad, and Ugly. Int J Lab Hematol. 2017;39 Suppl 1:98-103.

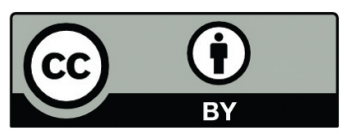

This work is licensed under a Creative Commons Attribution 